\title{
Reproductive Organs Present Indicator
}

National Cancer Institute

\section{Source}

National Cancer Institute. Reproductive Organs Present Indicator. NCI Thesaurus. Code C93655.

Specifies whether the anatomical parts of the body involved in reproduction are present or absent. 